\title{
Depth- and light-dependent variation of carbon partitioning and utilization in the zooxanthellate scleractinian coral Stylophora pistillata
}

\author{
J.-P. Gattuso ${ }^{1, *}$, D. Yellowlees ${ }^{2}$, M. Lesser ${ }^{3, * *}$ \\ ${ }^{1}$ Australian Institute of Marine Science, PMB No 3, Townsville MC, Queensland 4810, Australia \\ and \\ URA 1453 CNRS, Centre de Biologie et d'Ecologie Tropicale et Méditerranéenne, Laboratoire EPHE/Biologie Marine et \\ Malacologie, Université, F-66860 Perpignan Cedex, France \\ ${ }^{2}$ Department of Chemistry and Biochemistry, James Cook University, Townsville, Queensland 4811, Australia \\ ${ }^{3}$ Department of Zoology, University of Maine, Orono, Maine 04469, USA
}

\begin{abstract}
This study investigated the effect of light on the short-term metabolic fate of ${ }^{14} \mathrm{C}$-bicarbonate in zooxanthellae and animal tissue of the coral Stylophora pistillata (Esper, 1797) and on the specific activity of host enzymes involved in the metabolism of carbon. Short-term incubations of coral colonies were carried out in situ at Bowl Reef (Great Barrier Reef, Australia) at depths of 5 and $30 \mathrm{~m}$ to measure rates of oxygen production and consumption and rates of ${ }^{14} \mathrm{C}$ fixation. Short-term ${ }^{14} \mathrm{C}$ incubation experiments were also carried out under controlled conditions in the laboratory. Additional samples were collected from 5, 10,15 and $20 \mathrm{~m}$ at Chicken Reef (GBR) to determine the specific enzyme activity of coral tissues from different depths in the water column. Light and depth both affected the distribution of ${ }^{14} \mathrm{C}$ among photosynthetic products but neither affected translocation rate measured by the in vivo method $(60.4 \%)$. The majority of the ${ }^{14} \mathrm{C}$ label was recovered in lipid $(33$ to $94 \%)$ and watersoluble fractions (5 to $67 \%$ ). The zooxanthellae incorporated more ${ }^{14} \mathrm{C}$ into lipids than into watersoluble compounds ( 88 to $94 \%$ vs 4 to $7 \%$ ) while the animal exhibited higher ${ }^{14} \mathrm{C}$ levels in water-soluble compounds than in lipids ( 44 to $67 \%$ vs 33 to $56 \%$ ). Algal fractions showed decreased ${ }^{14} \mathrm{C}$ incorporation into lipids and increased ${ }^{14} \mathrm{C}$ incorporation into water-soluble compounds with increasing depth or decreasing irradiance. The specific activity of 3-hydroxyacyl CoA dehydrogenase increased with depth supporting the hypothesis that lipids are being catabolized more rapidly at greater depths. Citrate synthase and hexokinase activities also decreased with depth. The decrease in cytochrome oxidase activity with depth is consistent with a concomitant decrease in respiration as depth increases. These results confirm that the carbon cycling in S. pistillata is partially dependent on light.
\end{abstract}

\section{INTRODUCTION}

Translocation of photosynthetic products from zooxanthellae to the animal host plays an important role in the nutrition of scleractinian corals and thereby in the functioning of coral reef ecosystems. Despite the complexity of the energy fluxes within the symbiotic association, it is known that translocated photosynthates

Present addresses:

- Observatoire Océanologique Européen, Avenue SaintMartin, MC-98000 Monaco

- Bigelow Laboratory for Ocean Sciences, McKown Point, West Boothbay Harbor, Maine 04575, USA can supply more than $100 \%$ of the coral respiratory carbon requirements. The energy relationships of the symbiosis have recently been reviewed (Muscatine 1990).

Glycerol was first shown to be excreted by zooxanthellae isolated from corals (Muscatine 1967). Translocation of glycerol and other water-soluble compounds (e.g. glucose) has since been confirmed in many species and locations, and under different environmental conditions both in vitro and in hospite. This has lead to the belief that glycerol is the major translocate from the algae (see reviews by Trench 1979 and Cook 1983). 
The tissues of anthozoans, such as sea anemones and corals, are rich in lipid (Patton et al. 1977, Stimson 1987). The role of zooxanthellae in coral lipid metabolism has received considerable attention. Schmitz \& Kremer (1977) demonstrated a time-dependent conversion of glycerol to lipid using ${ }^{14} \mathrm{C}$ in intact tissues of the coral Acropora cf. splendens. Furthermore, Schmitz \& Kremer (1977) showed that deacylation of lipid yielded ${ }^{14} \mathrm{C}$-glycerol, which is supported by earlier results of Muscatine \& Cernichiari (1969). This also supported Young's suggestion that the host converts translocated glycerol into lipid (Young et al. 1971). Patton et al. (1977), however, showed that lipids can be directly transferred to the animal. They consequently proposed a carbon cycle involving reciprocal translocation between host and symbionts whereby zooxanthellae utilize host-derived carbon (probably acetate) for synthesis and subsequent excretion of fatty acids to the host for conversion into wax ester and triglyceride. Further evidence for translocation of insoluble compounds came from the discovery of lipid extrusion by zooxanthellae freshly isolated from the coral Stylophora pistillata (Esper, 1797) (Patton \& Burris 1983).

There is some controversy about which lipid moiety is labelled. Previous work (e.g. Muscatine \& Cernichiari 1969, Schmitz \& Kremer 1977) indicated that the majority of ${ }^{14} \mathrm{C}$ incorporated into lipids was recovered in the glycerol moiety of the host lipids, whereas subsequent research (e.g. Crossland et al. 1980, Patton et al. 1983) found the label to be more actively incorporated into the non-glycerol moiety. These later studies show that carbon is immediately incorporated into lipid and subsequently translocated to the host (Patton et al. 1983), and that the cycle suggested by Patton et al. (1977) was incorrect.

The general picture of carbon cycling in corals and tropical symbiotic cnidarians can be summarized as follows (see Patton et al. 1983, Battey \& Patton 1984): (1) carbon is quickly incorporated into a structural component that turns over very slowly; (2) carbon is also rapidly incorporated into an energy pool (lipids and sugars); (3) fixed carbon is translocated in several chemical forms to the host; (4) stored lipids can be used as an energy source while glycerol and other lowmolecular weight products are present as a small pool which turns over very quickly, are used as substrate for catabolism, and support basal metabolism; and (5), the relative contributions of these compounds to the carbon budget is unknown.

Research has only recently begun on the effect of environmental factors on carbon partitioning in corals. Muscatine et al. (1984, p. 196) have suggested that 'the quality of translocated products might differ with habitat irradiance' in Stylophora pistillata. Battey \& Porter
(1988) were the first to report a bathymetric change in photosynthate quality in Montastrea annularis and suggested that lipid synthesis was light stimulated.

Following analysis of metabolic quotients, Gattuso \& Jaubert (1990) suggested that zooxanthellae of the coral Stylophora pistillata predominantly produced carbohydrates in shallow water and lipids in deep water, and that these 2 substrates supply the respiratory requirements of the animal according to their availability. Recently, however, it has been suggested that the respiratory quotient is not an ecologically meaningful indicator of catabolic substrates in benthic marine invertebrates (Hatcher 1989). No such controversy surrounds the use of the photosynthetic quotient as an indicator of the quality of photosynthate of natural phytoplankton (Laws 1991, Williams \& Robertson 1991).

Our objectives were to investigate how depth and light affect the type of compounds: (1) synthesized by zooxanthellae; (2) translocated from zooxanthellae to host; and (3) used as respiratory substrate. The nature of photosynthesized and translocated compounds was investigated by fractionating labelled compounds after ${ }^{14} \mathrm{C}$ incubation both in situ and in the laboratory and the nature of catabolic substrate was examined using changes of host enzyme activities with depth. The specific activities of enzymes can provide important information on the regulatory and flux-generating steps in pathways of energy metabolism such as glycolysis, TCA cycle, electron transport chain, and $\beta$-oxidation of lipids (Hochachka \& Somero 1984, Newsholme \& Crabtree 1986) and, therefore, useful physiological information about metabolic fluxes. This does not preclude the possibility that control of carbon flux may occur via modulation of enzymes rather than by altering capacities by de novo synthesis. Studies on corals collected from different depths were used to estimate maximal metabolic capacities in vivo, and whether the hosts of these symbiotic cnidarians are metabolically poised to utilize different respiratory substrates.

\section{MATERIALS AND METHODS}

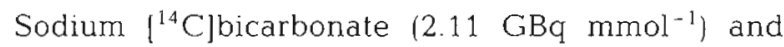
Biodegradable Counting Scintillant (BCS) were purchased from Amersham International. Fluorinert FC77 was obtained from 3M Australia Pty Ltd. Colonies of the zooxanthellate scleractinian coral Stylophora pistillata used for the measurement of oxygen fluxes and ${ }^{14} \mathrm{C}$ fixation were collected at Bowl Reef (Great Barrier Reef, Australia) in April 1990. Corals used for enzyme assays were collected at Chicken Reef (GBR) in March. 1989. 
${ }^{14} \mathrm{C}$ fixation experiments. Experimental conditions of the ${ }^{14} \mathrm{C}$ fixation experiments are summarized in Table 1 .

Table 1 Experimental conditions of in situ and laboratory experiments

\begin{tabular}{|lcccc|}
\hline & \multicolumn{2}{c}{ In situ } & \multicolumn{2}{c|}{ In the laboratory } \\
& $5 \mathrm{~m}$ & $30 \mathrm{~m}$ & \multicolumn{2}{c|}{$\begin{array}{c}\text { Colonies from: } \\
\end{array}$} \\
& & & & $30 \mathrm{~m}$ \\
& & & & 30 \\
\hline Temperature $\left({ }^{\circ} \mathrm{C}\right)$ & 29.4 & 29.1 & 27 & 27 \\
Light $\left(\mu \mathrm{mol} \mathrm{m}{ }^{-2} \mathrm{~s}^{-1}\right)$ & 671 & 158 & $700-800$ & $300-350$ \\
Duration $(\mathrm{min})$ & 60 & 68 & 60 & 60 \\
${ }^{14} \mathrm{C}$ activity $\left(\mu \mathrm{Ci} \mathrm{ml} \mathrm{ml}^{-1}\right)$ & 0.1 & 0.1 & 1 & 1 \\
\hline
\end{tabular}

In situ incubations: Isotope $\left({ }^{14} \mathrm{C}\right)$ incorporation experiments were performed in situ on the back reef of Bowl Reef at 5 and $30 \mathrm{~m}$ depth. Colonies ( $\mathrm{n}=8$ at $5 \mathrm{~m}$ and $n=10$ at $30 \mathrm{~m} ; 17.4$ to $68.3 \mathrm{~g}$ skeletal dry wt) were collected and cleaned of epiphytes $2 \mathrm{~d}$ prior to experiments. Colonies were placed in an open perspex incubation chamber approximately $18 \mathrm{~h}$ before the experiments commenced. At 10:30 h the following day, a UV-transparent perspex lid was sealed over the chamber (total volume: $12.5 \mathrm{l}$ ) and sodium $\left[{ }^{14} \mathrm{C}\right)$ bicarbonate was injected through a syringe needle port to produce a final specific activity of $3.7 \mathrm{KBq} \mathrm{m}^{-1}\left(=0.1 \mu \mathrm{Ci} \mathrm{ml}^{-1}\right)$. Seawater was continuously circulated at a flow rate of $12.8 \mathrm{l} \mathrm{min}^{-1}$ using a battery-powered bilge pump. The incubations lasted $60 \mathrm{~min}$ at $5 \mathrm{~m}$ and $68 \mathrm{~min}$ at $30 \mathrm{~m}$. The average irradiance, measured with a cosine corrected quantum sensor (LI-192SA, LI-COR, Lincoln, NE, USA), during experiments at 5 and $30 \mathrm{~m}$ was 663 and $161 \mu \mathrm{mol} \mathrm{m} \mathrm{m}^{-2} \mathrm{~s}^{-1}$ respectively. Upon termination of incubations, corals were brought to the ship, snap-frozen in liquid nitrogen and stored at $-20^{\circ} \mathrm{C}$ pending analysis.

Laboratory incubations: Colonies were collected at 5 and $30 \mathrm{~m}(\mathrm{~N}=6 ; 19.5$ to $56 \mathrm{~g}$ skeletal dry weight) immediately prior to experiment and maintained aboard ship in flowing seawater aquaria for 1 to $3 \mathrm{~h}$. The colonies were placed in a $300 \mathrm{ml}$ perspex chamber filled with Millipore $(0.45 \mu \mathrm{m})$ filtered seawater (FSW) and immersed in a bath of flowing seawater to control temperature (average temperature $27^{\circ} \mathrm{C}$ ). The incubation medium was continuously stirred using a magnetically-coupled stirring bar. Light was provided by 3 slide projectors. The irradiance ranged from 700 to $800 \mu \mathrm{mol} \mathrm{m} \mathrm{m}^{-2} \mathrm{~s}^{-1}$ during incubation of the corals collected at $5 \mathrm{~m}$. A shade clothe was used as a neutral density filter to reduce the irradiance to between 300 and $350 \mu \mathrm{mol} \mathrm{m} \mathrm{m}^{-2} \mathrm{~s}^{-1}$ for the deeper colonies. Corals were acclimated in light for $15 \mathrm{~min}$ before the addition of sodium $\left[{ }^{14} \mathrm{C}\right]$ bicarbonate to produce a final specific activity of $37 \mathrm{kBq} \mathrm{ml} l^{-1}\left(=1 \mu \mathrm{Ci} \mathrm{ml}{ }^{-1}\right)$. All incubations were of 60 min duration and were carried out between 09:45 and 14:15 h. Their duration was $60 \mathrm{~min}$. Corals were snap-frozen in liquid nitrogen at the conclusion of the experiment and stored at $-20^{\circ} \mathrm{C}$ pending analysis.

${ }^{14} \mathrm{C}$ partitioning and determination of radioactivity. Extraction of corals: Polyp tissue and zooxanthellae were separated from the skeleton using a polyfluorinated hydrocarbon (Fluorinert) according to the procedures described by Streamer et al. (1986). Zooxanthellae were separated from polyp tissue by centrifugation at $1000 \times g$ for $10 \mathrm{~min}$. The algal pellet was washed in three successive $5 \mathrm{ml}$ volumes of FSW and finally suspended in $5 \mathrm{ml} \mathrm{FSW}$. The supernatant from each wash was added to the original polyp supernatant fraction. Skeletal incorporation of ${ }^{14} \mathrm{C}$ was not measured. Dubinsky et al. (1983) found that 16 and $4 \%$ of the net carbon fixed in light-and shade-adapted Stylophora pistillata was incorporated into the mineral fraction of the skeleton.

Photosynthate partitioning: Both zooxanthellae and host tissues were treated similarly. Three $\mathrm{ml}$ of methanol:chloroform $(2: 1 \mathrm{v}: \mathrm{v})$ were added to $0.8 \mathrm{ml}$ of extract (zooxanthellae or animal). The tubes were vigorously shaken and left on ice for $45 \mathrm{~min}$. Distilled water $(1 \mathrm{ml})$ and chloroform $(1 \mathrm{ml})$ were added before centrifugation at $1000 \times g$ for $15 \mathrm{~min}$. The lower phase (chloroform fraction containing lipid) was removed with a Pasteur pipette and the upper phase was filtered (Whatman GF/C). The filtrate (methanol-water fraction containing aqueous compounds) was collected. The particulate fraction was retained on the filter and rinsed several times with distilled water.

Determination of radioactivity: Assimilation of sodium $\left[{ }^{14} \mathrm{C}\right]$ bicarbonate was measured on each of the 8 fractions: the whole zooxanthellae and host fractions, and the lipid, aqueous and particulate fractions derived from each. The filters (particulate fraction) were placed in glass scintillation vials $(20 \mathrm{ml})$, covered with $0.5 \mathrm{ml}$ of $20 \%$ ( $\mathrm{w}: \mathrm{v}$ ) trichloroacetic acid (TCA) to drive of unassimilated $\left({ }^{14} \mathrm{C}\right.$ )bicarbonate and $4 \mathrm{ml}$ of scintillation fluid (BCS) was added $30 \mathrm{~min}$ later. The remaining fractions were processed by adding $20 \%$ TCA $(0.25 \mathrm{ml})$ to duplicate samples $(0.25 \mathrm{ml})$. The vials were allowed to stand for at least $30 \mathrm{~min}$, with occasional shaking, before BCS $(4 \mathrm{ml})$ was added. Activity of extracts was measured using a LKB Wallac scintillation counter. The ${ }^{14} \mathrm{C}$ incorporated into each fraction (methanol-water, lipid and particulate) was expressed as a percentage of the total ${ }^{14} \mathrm{C}$ (sum of ${ }^{14} \mathrm{C}$ counts in the 3 fractions) recovered in either zooxanthellae or animal host tissues

Oxygen exchange. Rates of oxygen flux were meas- 
ured in situ using a 6-chamber respirometer comprising 6 galvanic oxygen sensors (EIL, Kent, UK), a stainless steel thermistor (Analog Devices model AC 2626 K4) and cosine corrected quantum sensor (LI-192SA). The oxygen sensors were calibrated each day against air-saturated seawater and a saturated solution of sodium dithionite (zero oxygen). A propeller located at the bottom of each chamber provided continuous stirring. Irradiance, dissolved oxygen and temperature were logged every minute. Corals were collected $24 \mathrm{~h}$ before measurement and cleaned of epiphytes and commensal crustaceans. Samples were incubated in UV-transparent perspex chambers (3.5 1). Rates of photo-synthesis were measured concomitantly with the ${ }^{14} \mathrm{C}$ assimilation on different colonies. Rates of respiration were measured at night over intervals of $33 \mathrm{~min}$ for $5 \mathrm{~m}$ corals and $44 \mathrm{~min}$ for $30 \mathrm{~m}$ corals. Samples were frozen for subsequent determination of chlorophyll and protein. Rates of photosynthesis and respiration were estimated by regressing oxygen data against time. Data were normalized by chlorophyll a or protein contents. Data obtained with 2 corals at $5 \mathrm{~m}$ could not be used due to unstable readings of the oxygen sensors.

Cell-iree extracts of host tissue. Colonies of Stylophora pistillata were collected at 5, 10, 15 and $20 \mathrm{~m}$ at Chicken Reef, subsequently transported to the Australian Institute of Marine Science in flowing seawater aquaria and processed within 48 h of collection. Specimens from each depth $(n=3)$ were crushed between a double layer of cheese cloth in $10 \mathrm{ml}$ of 100 $\mathrm{mM}$ phosphate buffer ( $\mathrm{pH} 7.6$ ) inside a plastic bag. All subsequent steps were performed at $4{ }^{\circ} \mathrm{C}$ in order to minimize the effect of proteases and the possibility of enzyme breakdown. The crude homogenate was centrifuged at $500 \times g$ for $20 \mathrm{~min}$ and the supernatant removed. The animal supernatant was sonicated on ice and centrifuged for $30 \mathrm{~min}$ at $16000 \times \mathrm{g}$ to obtain a cell-free extract for enzyme and protein determination. The cell-free extract was frozen, and flown to the University of Maine (USA) for enzyme and protein analysis

Measurement of flux generating or rate limiting enzymes. Cell-free extracts of hosts tissues were used to measure the protein-specific activities of enzymes associated with pathways of energy metabolism in the host including glycolysis, TCA cycle, electron transport chain, and $\beta$-oxidation of lipids. Enzyme measurements were made at the temperature of seawater at the collection site using optimized substrate concentration and $\mathrm{pH}$ according to the method given by Crokett \& Sidell (1990). Activities of: hexokinase (HK; EC 2.7.1.1), carnitine palmitoyltransferase (CPT; EC 2.3.1.21), 3-hydroxyacyl CoA dehydrogenase (HOAD; EC 1.1.1.35), citrate synthase (CS; EC 4.1.3.7) and cyto- chrome oxidase (CYTOX; EC 1.9.3.1) were normalized to protein to determine specific activities.

Chlorophyll and protein determinations. The content of chlorophyll a was measured on the colonies used for the measurement of oxygen exchange. Two consecutive extractions ( $24 \mathrm{~h}$ each) were performed using $100 \%$ acetone. Absorbance was measured at 630 and $663 \mathrm{~nm}$. Chlorophyll a content was estimated from the equation of Jeffrey \& Humphrey (1975). Protein content of the algal and animal fractions, and of the whole corals used for oxygen fluxes measurements were solubilized by adding $\mathrm{NaOH}$ to the samples (final concentration: $1 \mathrm{~N}$ ) and heating at $90^{\circ} \mathrm{C}$ for $30 \mathrm{~min}$. Samples were allowed to cool and neutralised with $\mathrm{HCl}$. Protein was measured against a series of standards using the method given by Bradford (1976) with Commasie Brilliant Blue G-250 (Bio-Rad laboratories). Bovine gamma globulin (Bio-Rad Laboratories) provided the standard except for corals used for the measurement of enzyme activity where the microbiuret procedure of Itzhaki \& Gill (1964) and bovine serum albumin standards (Sigma) were used.

Statistics. Results were analysed using the statistical package SuperAnova (Abacus Concepts Inc., Berkeley, CA, USA). Analysis of variance (ANOVA) and multivariate analysis of variance (MANOVA) were used to test the effect of depth and experimental condition (in situ vs in the laboratory). The 4 MANOVA statistics computed [Roy's largest root statistic, Wilk's lambda, Hotelling trace and Pillai's trace; see Abacus Concepts (1990)] generally gave similar conclusions. An arcsine transformation (Zar 1984) was used to normalize the distribution of the percentage data before using the ANOVA. Upper and lower confidence limits (based on standard errors) of percentages are explicitly given since confidence limits of proportions are generally not symmetrical around the mean (Zar 1984).

\section{RESULTS}

\section{Chlorophyll content and biomass ratio}

Chlorophyll a content increased from 5 to $30 \mathrm{~m}$ (Table 2) although the difference was not statistically significant ( $p=0.058$ ). The alga : coral protein biomass ratio (Table 2) did not display a significant difference with depth $(\mathrm{p}=0.57)$ or experimental conditions $(\mathrm{p}=$ $0.13)$. The average ratio was $5.7 \%$ (CI: 5.2 to $6.3 \% ; n=$ 29). This ratio is much lower than that obtained by Muscatine \& Cernichiari (1969) for Pocillopora damicornis $(49.9 \%)$ but very similar to that measured for Stylophora pistillata in the Red Sea by Muscatine et al. (1984; 4 to $5.1 \%$ ). 
Table 2. Alga: coral protein biomass ratio $(1-B)$ of the colonies used for ${ }^{14} \mathrm{C}$ fixation and chlorophyll $a$ :protein ratio of the colonies used for the measurement of oxygen exchange.

Mean - SE: sample sizes are shown in parentheses

\begin{tabular}{|cccc|}
\hline Depth & \multicolumn{2}{c|}{$1-B(\%)$} & Chl a: protein \\
Lab & In situ & $\left(\mu \mathrm{mg}^{-1}\right.$ protein $)$ \\
\hline $5 \mathrm{~m}$ & $\begin{array}{c}6.8 \pm 1.3 \\
(6)\end{array}$ & $\begin{array}{c}4.8 \pm 0.7 \\
(8)\end{array}$ & $\begin{array}{c}22.4 \pm 0.5 \\
(4)\end{array}$ \\
$30 \mathrm{~m}$ & $\begin{array}{c}7.0 \pm 0.8 \\
(6)\end{array}$ & $\begin{array}{c}6.0 \pm 1.2 \\
(9)\end{array}$ & $\begin{array}{c}28 \pm 2 \\
(6)\end{array}$ \\
& & & $(6)$ \\
\hline
\end{tabular}

\section{Productivity and translocation}

The net photosynthetic rate $(p)$ of intact corals estimated by the oxygen method, expressed per unit of protein (/prot) and chlorophyll a (/chl), decreased from 5 to $30 \mathrm{~m}$ (Table 3 ). The difference is statistically significant when $p$ is normalized against chlorophyll a $(\mathrm{p}=$ 0.0008 ) but is not statistically significant when normalized against protein $(p=0.051)$. Respiration rate normalized by both chlorophyll $a$ and protein decreased between 5 and $30 \mathrm{~m}$ (/prot, $\mathrm{p}=0.041_{i} / \mathrm{chl}, \mathrm{p}=0.002$ ). There was also a significant effect of depth $(p=0.001)$, and condition of measurement (laboratory versus in situ; $\mathrm{p}=0.003$ ) on total ${ }^{14} \mathrm{C}$ incorporation. Productivity estimated from oxygen measurements declined with depth whereas productivity estimated by ${ }^{14} \mathrm{C}$ fixation increased (Table 3).

At the end of the incubation period, a significant amount of the fixed ${ }^{14} \mathrm{C}$ was recovered in the animal fraction. The translocation rate, the amount of ${ }^{14} \mathrm{C}$ recovered in the animal fraction expressed as a percentage of total ${ }^{14} \mathrm{C}$ fixed, did not depend on depth $(\mathrm{p}=$ $0.17)$ nor experimental condition ( $p=0.36)$. The average translocation rate was $60.4 \%$ (Cl: 59.5 to $61.5 \%$; $n=30$ ).

\section{Photosynthate partitioning}

The ${ }^{14} \mathrm{C}$ recovery, estimated as percentage of the total ${ }^{14} \mathrm{C}$ count in methanol-water, chloroform and particulate fractions was, on average, $62.6 \%$ (CI: 61.6 to $63.8 \% ; n=30$ ). Acidification of the aqueous, lipid and particulate fractions resulted in quantitative release of inorganic carbon in these samples.

MANOVAs showed that both the depth of collection and the experimental conditions have a simultaneous and significant effect on the partitioning of photosynthates into the 3 fractions studied ( $p=0.0001$ for both factors). Significant interaction was also detected between the 2 factors ( $p=0.019$ ), which demonstrates that the effect of depth depends on the experimental conditions.

Lipid was the main labelled compound recovered in the algal fraction of colonies incubated in situ (Fig. 1A, B). There was a slight, statistically significant decrease of zooxanthellar-labelled lipid between 5 and $30 \mathrm{~m}$ (92.1 vs $87.9 \% ; p=0.009$ ). The aqueous and particulate pools represented less than $10 \%$ of the total radioisotope incorporation in the algae at $5 \mathrm{~m}$ and increased
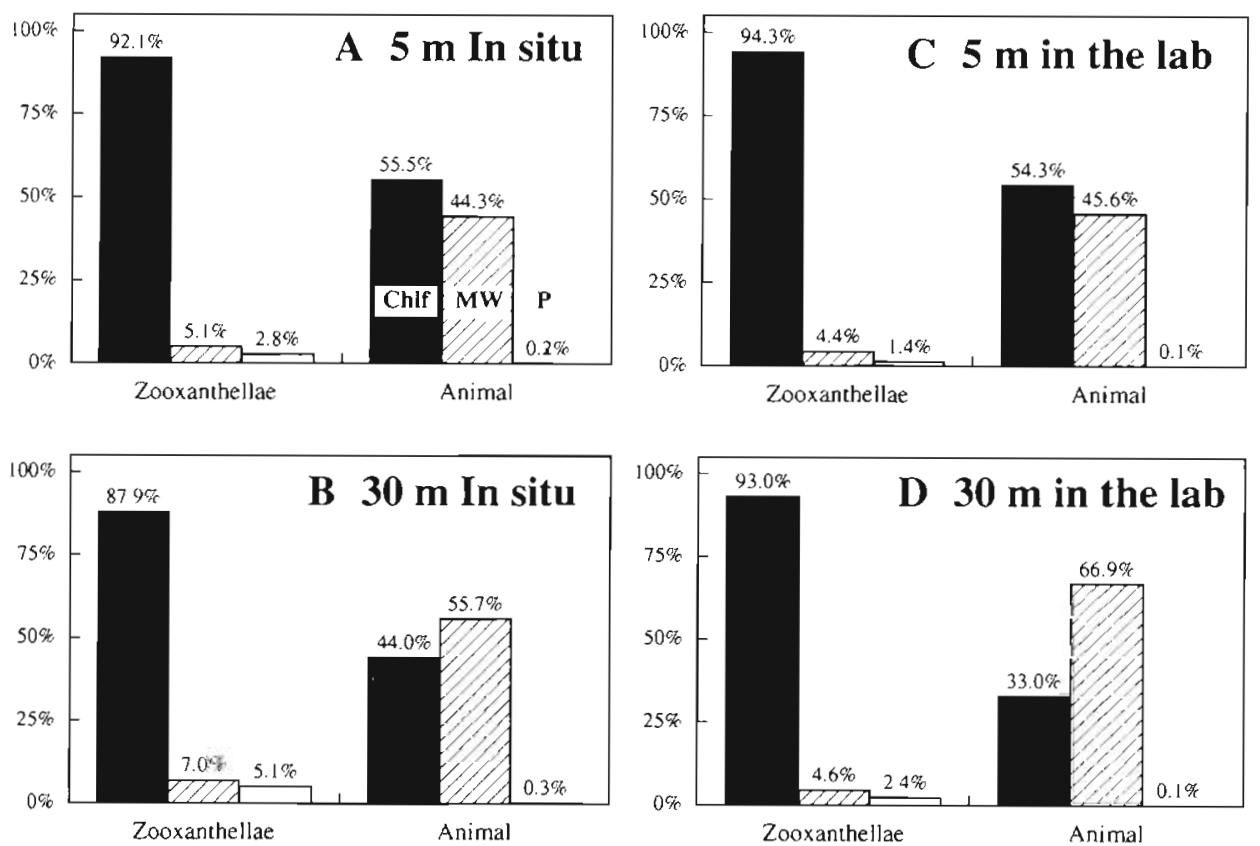

Fig. 1. Proportion of radioactivity recovered in the chloroform (Chlf), methanol-water (MW) and particulate (P) fractions of zooxanthellae and host tissue 
Table 3. Rate of ${ }^{14} \mathrm{C}$ fixation, translocation (expressed as a percentage of fixed ${ }^{14} \mathrm{C}$ recovered in coral animal tissue) and rates of net photosynthesis and respiration expressed per unit of protein or chlorophyll a (=/prot or /chl). ${ }^{14} \mathrm{C}$ fixation rate: $\mathrm{cpm}$ (mg protein) ${ }^{-1}$

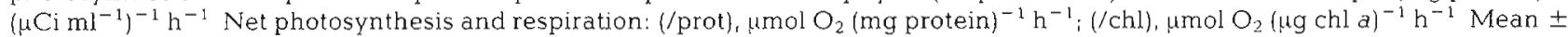
$S E_{i}$ sample sizes are shown in parentheses

\begin{tabular}{|c|c|c|c|}
\hline & $\begin{array}{c}\text { Experimental } \\
\text { conditions }\end{array}$ & $5 \mathrm{~m}$ & $30 \mathrm{~m}$ \\
\hline${ }^{14} \mathrm{C}$ fixation rate & Lab & $\begin{array}{c}8500.6 \pm 1024.6 \\
(6) \\
14723.2 \pm 1451.8 \\
(8)\end{array}$ & $\begin{array}{c}15660.3 \pm 1699.6 \\
(6) \\
24510.2 \pm 2740.3 \\
(9)\end{array}$ \\
\hline Translocation (\%) & $\begin{array}{l}\text { Lab } \\
\text { In situ }\end{array}$ & $\begin{array}{c}65.2 \pm 1.9 \\
(6) \\
58.8 \pm 1.8 \\
(8)\end{array}$ & $\begin{array}{c}57.9 \pm 1.9 \\
(6) \\
60.7 \pm 1.9 \\
(9)\end{array}$ \\
\hline Net photosynthesis (/prot) & In situ & $\begin{array}{c}2.75 \pm 0.12 \\
(4)\end{array}$ & $2.04 \pm 0.24$ \\
\hline Respiration (/prot) & In situ & $0.77 \pm 0.07$ & $\begin{array}{c}0.59 \pm 0.04 \\
(6)\end{array}$ \\
\hline Net photosynthesis (/chl) & In situ & $\begin{array}{c}123.12 \pm 7.63 \\
(4)\end{array}$ & $\begin{array}{c}72.61 \pm 6.05 \\
(6)\end{array}$ \\
\hline Respiration (/chl) & In situ & $\begin{array}{c}34.63 \pm 2.44 \\
(4)\end{array}$ & $\begin{array}{c}21.35 \pm 1.79 \\
(6)\end{array}$ \\
\hline
\end{tabular}

slightly with increasing depth (aqueous fraction: 5.1 to $7.0 \%$; particulate fraction: 2.8 to $5.1 \%$ ). The proportions of the 3 classes of compounds varied significantly in the algal and animal fractions. The radioactivity recovered in animal lipid was still important and decreased with depth (55.5 vs $44.0 \%$ ). The aqueous fraction was a major fraction contributing 44.3 and $55.7 \%$, respectively at 5 and $30 \mathrm{~m}$, of the ${ }^{14} \mathrm{C}$ recovered in animal tissues. The label recovered in the particulate fraction was of negligible importance (less than $0.3 \%$ ). Similar results were obtained with colonies incubated under laboratory conditions (Fig. 1C, D) although the decrease of label in the zooxanthellar lipid fraction was less pronounced than in situ.

\section{Enzyme activity}

The protein content of the animal host showed no significant difference with depth (ANOVA: $p=0.28$ ); the average protein content was $3.45 \pm 0.28$ (mg colony ${ }^{-1} \pm \mathrm{SD} ; \mathrm{n}=9$ ). Depth had no simultaneous effect on the specific activities of the enzymes studied (MANOVA, $p>0.05$ ). There was, however, a significant effect of depth on the specific activities of $\mathrm{HK}, \mathrm{CS}$ and CYTOX as shown by separate ANOVAs (HK, p = 0.049 ; CS, $p=0.033$; CYTOX, $p=0.045)$ HK and CS decrease with depth (Fig 2A, B), CYTOX activities seem to be fairly constant between 5 and $15 \mathrm{~m}$ but decreased by $63 \%$ between 15 and $20 \mathrm{~m}$. CPT showed no variation (ANOVA: $p=0.99$ ). In contrast, HOAD
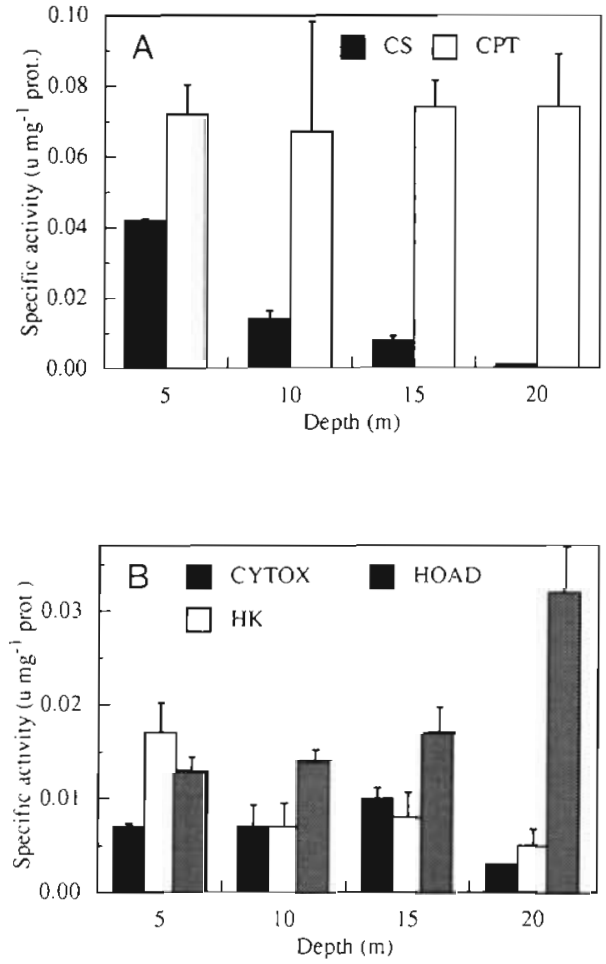

Fig. 2. Protein specific activities ( $n=3$, mean \pm SD) of 5 fluxgenerating or rate-limiting enzymes in host tissues of the scleractinian coral Stylophora pistillata. (A) CS: citrate synthase; CPT: carnitine palmitoyl transferase. (B) CYTOX: cytochrome oxidase; HK: hexokinase; HOAD: 3-hydroxyacyl CoA dehydrogenase 
showed an increase in specific activity with increasing depth (Fig. 2 B; ANOVA: p $=0.008$ )

\section{DISCUSSION}

The rates of net and gross photosynthesis $(p)$ decrease with depth when expressed per unit of chlorophyll a or protein. The maximum rate of gross photosynthesis $\left(p_{m}\right)$ of corals on a chlorophyll a basis usually decreases as a function of decreasing irradiance levels but increases if biomass is expressed in terms of protein content (see the recent review by Barnes \& Chalker 1990). However, the incubations took place during the late morning $(10: 30$ to $11: 30 \mathrm{~h})$ and photosynthesis-irradiance curves displayed by the same species on the Great Barrier Reef (Gattuso unpubl.) show that corals were subject to sub-saturating irradiance, especially at $30 \mathrm{~m}$. Therefore, the rates of photosynthesis reported in the present paper are not the maximum rates of photosynthesis which explains why $p$ normalized to the protein content did not display the expected increase with depth. The main purpose of the ${ }^{14} \mathrm{C}$ fixation experiments was to study the partitioning of photosynthetic products but the data could also be used to estimate primary productivity. The rate of ${ }^{14} \mathrm{C}$ fixation per unit of protein increased with depth. However, the use of this technique for estimating coral productivity has many drawbacks: recycling of fixed carbon during long-term incubations, isotopic disequilibrium in short-term incubations, and the uncertainty of whether ${ }^{14} \mathrm{C}$ fixation measures net or gross photosynthesis (see Muscatine 1990). For these reasons, it is difficult to compare the rates of productivity from ${ }^{14} \mathrm{C}$ fixation data with rates derived from the $\mathrm{O}_{2}$ electrode measurements. The matter is further complicated by results which show that 50 to $60 \%$ of photosynthetically-fixed ${ }^{14} \mathrm{C}$ can be lost over a period of $40 \mathrm{~h}$ after incubation as mucus, dissolved organic carbon and respiratory $\mathrm{CO}_{2}$ (Crossland et al. 1980). We have not attempted to estimate this loss but think that it is likely to be significant for deep-water corals but not for shallow-water corals since Muscatine et al. (1984) showed that light-adapted colonies of Stylophora pistillata released only $6 \%$ of the total fixed carbon over a period of $24 \mathrm{~h}$ whereas shade-adapted colonies released almost $50 \%$ of the total fixed carbon. The rates reported here may, therefore, underestimate the productivity.

Night-time fixation was not measured since heterotrophic ${ }^{14} \mathrm{C}$ fixation in darkness, expressed as the percentage of photosynthetic fixation, was found to be very small, ca $3 \%$, in short-term (60 min) incubation of the coral Acropora cf. splendens (Schmitz \& Kremer 1977). The ${ }^{14} \mathrm{C}$ fixation of the coral Montastrea annu- laris, measured under ambient light during long-term experiments $(24 \mathrm{~h})$ and expressed per unit of surface area is not correlated with depth: it remains more or less constant from 9 to $15 \mathrm{~m}$, decreases sharply at $24.5 \mathrm{~m}$ and increases from 24.5 to $33.5 \mathrm{~m}$ (Barnes \& Taylor 1973). The effect of depth on the rate of ${ }^{14} \mathrm{C}$ fixation (normalized to insoluble residue) was shown to be species-dependent: it tends to decrease with increasing depth in $S$. pistillata but increases in $A$. variabilis (Erez 1978). Extrapolating from the results of Battey \& Porter (1988), ${ }^{14} \mathrm{C}$ fixation in the coral $M$. annularis (normalized to protein content) decreases by $30 \%$ between 5 and $30 \mathrm{~m}$. This result, however, may have been affected by the lack of water motion during the experiments.

The average translocation rate measured in this study $(60.4 \%)$ is higher than the rate measured on the same species in the Red Sea using a similar in vivo method (37 to $38 \%$; Muscatine et al. 1984). Translocation rates measured by partitioning ${ }^{14} \mathrm{C}$ between algal and animal fractions in a wide range of zooxanthellate cnidarians range from 20 to $58 \%$ of total ${ }^{14} \mathrm{C}$ fixed by photosynthesis (see review by Trench 1979). It is now well established, however, that the in vivo technique seriously underestimates the rate of translocation and that rates are in the range of 78 to $98 \%$ (Muscatine 1990) for cnidarians in general and over $95 \%$ in Stylophora pistillata (Muscatine et al. 1984). This discrepancy was suggested to be the result of the translocation of unlabelled compounds (Muscatine et al. 1984). In addition, the translocation rate was shown to vary depending on the time of incubation (Black \& Burris 1983).

These figures refer to total translocation; however, translocation is a selective process which was shown to display a high degree of variability depending on the quality of photosynthate. For example, the intracellular concentration of ${ }^{14} \mathrm{C}$-labelled glycerol is only $3.6 \%$ in zooxanthellae isolated from the sea anemone Anthopleura elegantissima even though glycerol comprises $43 \%$ of the extracellular products (Trench 1971). On the other hand, in the same species, glucose represents $32.5 \%$ of the intracellular products but only $0.5 \%$ of extracellular products. It is difficult to extrapolate from these figures obtained for isolated zooxanthellae to a situation in hospite.

In the coral Stylophora pistillata, the effect of light on the quality of photosynthates produced by the zooxanthellae, then translocated to the host and used as respiratory substrate has been investigated using 3 different methods of investigation: (1) changes in metabolic quotients with depth (Gattuso \& Jaubert 1990); (2) photosynthate partitioning in the algae and the host both at different depths and under correspondingly different light intensity in the laboratory (present study); and 
(3) host enzyme activities at different depths (present study). This makes a unique set of data despite the fact that the corals were not collected at the same location or season. Using metabolic quotients Gattuso \& Jaubert (1990) suggested that glycerol is the principle compound synthesized, translocated and catabolized by shallow-water corals and that it is replaced by lipids with increasing depth. Specific enzyme activities within animal tissues of Stylophora pistillata collected from depths of 5 to $20 \mathrm{~m}$ generally agree with these results (Fig. 2), and show the host metabolically poised to take advantage of different respiratory substrates at different depths.

An increase in the specific activity of 3-hydroxyacyl CoA dehydrogenase, an indicator of fatty acid oxidation, with depth supports the hypothesis that lipids are preferentially respired as depth increases, although the specific activity of carnitine palmitoyltransferase, which is involved in the transfer of fatty acids across the mitochondrial membrane, was not depth-dependent. Citrate synthase and hexokinase activities also decreased with depth. Citrate synthase is the ratelimiting step of the TCA cycle, and a decrease in specific activity may be a result of negative modulation by ATP. The net ATP yield per carbon atom is significantly higher from fatty acids than carbohydrates. The activity of cytochrome oxidase, a marker of aerobic capacity, is similar throughout the depth range of 5 to $15 \mathrm{~m}$ but decreases between 15 and $20 \mathrm{~m}$. This decrease in cytochrome oxidase with depth is consistent with the observed decrease in respiration rate as depth increases. Our ability to interpret the glycolytic flux at shallow depths is hampered by having no estimation of glyceraldehyde 3-phosphate dehydrogenase (GPD; EC 1.2.1.12) activity, since it is likely that translocated glycerol enters the glycolytic pathway at this point. Further studies of host enzymes should include measurement of phosphofructokinase and GPD. Both of these enzymes should provide better indicators of glycolytic flux due to the oxydation of glycerol.

The partitioning of ${ }^{14} \mathrm{C}$ compounds partly supports the conclusion drawn from the depth-related changes in metabolic quotients and enzyme activities. The lipid pool is quantitatively the most important pool recovered in zooxanthellae at 5 and $30 \mathrm{~m}$ ( 88 to $94 \%$ ), followed by the methanol-water and the particulate fractions. These findings are supported by other data for Stylophora pistillata showing that the percentage of total host radioactivity contained within lipids rises from 35 to $40 \%$ immediately after incubation, to 70 to $90 \% 60$ min later (Patton et al. 1983). We are unable to determine if carbon is incorporated into the glycerol or the fatty acid moiety of the lipid. Schmitz \& Kremer (1977) demonstrated that glycerol, phosphoglyceric acid and other water-soluble compounds appear within 3 min of photosynthesis in the coral Acropora cf. splendens. We found only small amounts of ${ }^{14} \mathrm{C}$ appearing within the methanol-water fraction, which is not unexpected given that glycerol probably represents the bulk of this fraction and its intracellular concentration in zooxanthellae is very low (Trench 1971). This suggests that the methanol-water fraction represents a small pool with a high turn over. More ${ }^{14} \mathrm{C}$ entered lipids in zooxanthellae of shallow than deep colonies; the opposite was found with the methanolwater compounds. These results accord with an elevated lipid synthesis as depth increases provided that lipids are more readily translocated and consumed in deeper corals

More intensive fractionation has identified and quantified ${ }^{14} \mathrm{C}$ incorporation into 5 separate fractions in the coral Montastrea annularis (Battey \& Porter 1988): protein, lipid, water-soluble, oligosaccharides and oligonucleotides, and nucleic acids arranged in order of diminishing ${ }^{i+} \mathrm{C}$ incorporation. Low incorporation of ${ }^{24} \mathrm{C}$ occurs into lipid of zooxanthellae from $M$. annularis at sunset, but it is more or less constant for the major proportion of the day. Battey \& Porter (1988) interpreted the time-dependent incorporation of ${ }^{14} \mathrm{C}$ into lipid as evidence of light-stimulated lipid synthesis. This is not consistent with our conclusion, based on both ${ }^{14} \mathrm{C}$ incorporation and estimation of lipid catabolism, of an increased lipid synthesis with decreasing light (increasing depth) unless a differential effect of - light quality and intensity is involved.

Light has both a quantitative and a qualitative effect. Colonies incubated in situ at 5 and $30 \mathrm{~m}$ experienced qualitatively different light regimes, with the deeper corals receiving proportionately more blue and green radiation and less red radiation than shallow-water corals. Colonies incubated in the laboratory, however, received light of identical spectral distribution. The observed interaction between depth of collection and experimental conditions on the proportion of ${ }^{14} \mathrm{C}$ recovered into the 3 fractions studied in the algae and host tissue might indicate an effect of light quality. The relative changes of these fractions were, however, similar in situ and in the laboratory. This result suggests, with possible exception of the lipid pool which decreased more rapidly when light quality changes with depth (in situ), that the effect of light intensity on photosynthate quality is more significant than the effect of light quality. Battey \& Porter (1988) studied the quality of photosynthate by incubating colonies: (1) at the same depth but at different times (change in light intensity only) and (2) at different depths, approximately at the same period of the day (change in both light intensity and quality). Of the 5 fractions they investigated, only the lipid and protein fractions displayed significant variation with depth. The water 
soluble-pool did not display any significant variation with depth. Lipids increased from 0.5 to $20 \mathrm{~m}$ and decreased from 20 to $50 \mathrm{~m}$, proteins decreased with increasing depth

The changes in enzyme activities appear to support previous suggestions that light-dependent modulation of carbon cycling occurs in the coral Stylophora pistillata. The partitioning of photosynthetically fixed ${ }^{14} \mathrm{C}$ in zooxanthellae partly supports this interpretation but does not provide absolute rates of flux because there is no way of estimating the extent to which translocated products are biochemically modified within the coral host. The lack of continuous sampling when considering the importance of a particular biochemical fraction over a wide depth range (e.g. the variation of lipids in zooxanthellae observed in Montastrea annularis between 0.5 and $50 \mathrm{~m}$; Battey \& Porter 1988) precludes formulation of a general conclusion on the effect of depth when only a portion of the bathymetric range is investigated. The results do, nonetheless, support conclusions drawn from changes of metabolic quotients are valid despite recent contention that respiratory quotients (RQs) are not appropriate indicators of the nature of catabolic substrates (Hatcher 1989). Hatcher's arguments are based on the measurement of RQs well outside the theoretical limits $(0.7$ to 1.0$)$ during laboratory incubations in open chambers. Such problem was not experienced during in situ incubations in closed chambers by Gattuso \& Jaubert (1990; 1 outlier out of 16 RQs). It is suggested here that dubious results based on metabolic quotients occur as a consequence of inadequate experimental procedure and not from poor correlation between the value of $R Q$ and the nature of catabolic substrate. Hatcher (1989) assumed that the $\mathrm{CO}_{2}$ exchange across the air-water interface above the open-topped chambers was negligible and estimated the $\mathrm{O}_{2}$ exchange; small inaccuracies in one or both fluxes may result in large changes in $R Q$ and explain the outliers. The problem of substrate switching during the experiments suggested by Hatcher (1989) is, however, certainly relevant and probably does not allow complete characterization of catabolic substrates based on values for $R Q$.

Acknowledgements. This research was partly supported by an AIMS Post-Doctoral Fellowship. We thank the AIMS' workshops for development of the respirometer and for skillfull technical assistance. Assistance in the field was provided by the Master and crew of the RV 'Lady Basten', C. Battershill, J. Killian and S. Schultz. Special thanks to J Chisholm for his invaluable help during the cruise and for his critical review of the manuscript, and to P. Sammarco for collecting the colonies used for the measurement of the enzyme activities. We also thank D. Barnes, B. Chalker, M. Shick and $B$. Sidell for commenting on an earlier draft of the manuscript. Contribution 697 of the Australian Institute of Marine Science.

\section{LITERATURE CITED}

Abacus Concepts Inc. (1990). Accessible general linear modelling. Abacus Concepts Inc., Berkeley

Barnes, D. J., Chalker, B. E. (1990). Calcification and photosynthesis of reef-building coral and algae. In: Dubinsky, $Z$. (ed.) Coral reefs. Elsevier, Amsterdam, p. 109-131

Barnes, D. J., Taylor, D. L. (1973). In situ studies of calcification and photosynthetic carbon fixation in the coral Montastrea annularis. Helgoländer Wiss. Meeresunters. 24: 284-291

Battey, J. F., Patton, J. S. (1984). A reevaluation of the role of glycerol in carbon translocation in zooxanthellae-coelenterate symbiosis. Mar. Biol. 79: 27-38

Battey, J. F., Porter, J. W. (1988). Photoadaptation as a whole organism response in Montastrea annularis. Proc. 6th int. coral Reef Symp. 3: 79-87

Black, C. C., Burris, J. E. (1983). Diurnal carbon-14 partitioning between zooxanthellae and the coral animal tissue of intact Seriatopora hystrix colonies. Mar. Biol. 75: 117-120

Bradford, M. M. (1976). A rapid and sensitive method for the quantitation of microgram quantities of protein utilizing the principle of protein dye binding. Anal. Biochem. 72: $248-254$

Cook, C. B. (1983). Metabolic interchange in algae-invertebrate symbiosis. Int. Rev. Cytol. Supp. 14: 177-210

Crokett, E. L., Sidell, B. D. (1990). Some pathways of energy metabolism are cold adapted in Antarctic fishes. Physiol. Zool. 63: 472-488

Crossland, C. J., Barnes, D. J., Borowitzka, M. A. (1980). Diurnal lipid and mucus production in the staghorn coral Acropora acuminata. Mar. Biol. 60: 81-90

Dubinsky, Z., Falkowski, P. G., Sharf, D. (1983). Aspects of adaptation of hermatypic corals and their endosymbiotic algae to light. Bull. Inst. Oceanogr. Fish. 9: 124-134

Erez, J. (1978). Vital effect on stable-isotope composition seen in Foraminifera and coral skeletons. Nature 273: 199-202

Gattuso, J.-P., Jaubert, J. (1990). Effect of light on oxygen and carbon dioxide fluxes and on metabolic quotients measured in situ in a zooxanthellate coral. Limnol. Oceanogr. 35: $1796-1804$

Hatcher, A. (1989). RQ of benthic marine invertebrates. Mar. Biol. 102: 445-452

Hochachka, P. W., Somero, G. N. (1984). Biochemical adaptation. Princeton Univ. Press, Princeton

Itzhaki, R. F., Gill, D. M. (1964). A micro-biuret method for estimating proteins. Anal. Biochem. 9: 401-410

Jeffrey, S. W., Humphrey, G. F. (1975). New spectrophotometric equations for determining chlorophyll $a_{2} b, c_{1}$ and $c_{2}$ in higher plants, algae and natural phytoplankton. Biochem. Physiol. Pflanzen 167: 191-194

Laws, E. A. (1991). Photosynthetic quotients, new production and net community production in the open ocean. Deep Sea Res. 38: 143-167

Muscatine, L. (1967). Glycerol excretion by symbiotic algae from corals and Tridacna and its control by the host. Science 156: $516-518$

Muscatine, L. (1990). The role of symbiotic algae in carbon and energy flux in reef corals. In: Dubinsky, Z. (ed.) Coral reefs. Elsevier, Amsterdam, p. 75-87

Muscatine, L., Cernichiari, E. (1969). Assimilation of photosynthetic products of zooxanthellae by a reef coral. Biol. Bull. 137: 506-523

Muscatine, L., Falkowski, P. G., Porter, J. W., Dubinsky, Z. (1984). Fate of photosynthetic fixed carbon in light- and 
shade-adapted colonies of the symbiotic coral Stylophora pistillata. Proc. R. Soc. Lond. 222: 181-202

Newsholme, E. A., Crabtree, B. (1986). Maximum catalytic activity of some key enzymes in provision of physiologically useful information about metabolic fluxes. J. exp. Zool. 239: 159-167

Patton, J. S., Abraham, S., Benson, A. A. (1977). Lipogenesis in the intact coral Pocillopora capitata and its isolated zooxanthellae. Evidence for a light-driven carbon cycle between symbiont and host. Mar. Biol. 44: 235-247

Patton, J. S., Battey, J. F., Rigler, M. W., Porter, J. W., Black, C. C., Burris, J. E. (1983). A comparison of the metabolism of bicarbonate ${ }^{14} \mathrm{C}$ and acetate $1-{ }^{14} \mathrm{C}$ and the variability of species lipid composition in reef corals. Mar. Biol. 75: $121-130$

Patton, J. S., Burris, J. E. (1983). Lipid synthesis and extrusion by freshly isolated zooxanthellae (symbiotic algae). Mar. Biol. 75: 131-136

Schmitz, K., Kremer, B. P. (1977). Carbon fixation and analysis of assimilates in a coral-dinoflagellate symbiosis. Mar. Biol. 42: 305-313

Stimson, J. S. (1987). Location, quantity and rate of change in

This article was submitted to the editor quantity of lipids in tissue of Hawaiian hermatypic corals. Bull. mar. Sri. 41: 889-904

Streamer, M., McNeil, Y., Yellowlees, D. (1986). The shortterm partitioning of carbon-14 assimilate between zooxanthellae and polyp tissue in Acropora formosa. Mar. Biol. 90: $565-573$

Trench, R. K. (1971). The physiology and biochemistry of zooxanthellae symbiotic with marine coelenterates. II Liberation of fixed ${ }^{14} \mathrm{C}$ by zooxanthellae in vitro. Proc. $\mathrm{R}$. Soc. Lond. 177: 237-250

Trench, R. K. (1979). The cell biology of plant-animal symbiosis. A. Rev. Plant. Physiol. 30: 485-531

Williams, P. J. leB., Robertson, J. E. (1991). Overall planktonic oxygen and carbon dioxide metabolisms: the problem of reconciling observations and calculations of photosynthetic quotients. J. Plankton Res. 13 Suppl.. 153-169

Young, S. D., O'Connor, J. D., Muscatine, L. (1971). Organic material from scleractinian coral skeletons. II. Incorporation of ${ }^{14} \mathrm{C}$ into protein, chitin and lipid. Comp. Biochem. Physiol. B40: 945-958

Zar, J. H. (1984). Biostatistical analysis, 2nd edn. PrenticeHall, Englewood Cliffs

Manuscript first received: July 17,1992

Revised version accepted: November 26, 1992 